\title{
The Failure of New Political Parties and ID Figures: Nobility of Technocrats in Analysis of Voting Behavior in Jambi
}

\author{
Hatta Abdi Muhammad ${ }^{1)}$ *, Nopyandri ${ }^{2)}$ \\ 1) Political Science Study Program, Faculty of Law, Jambi University \\ 2) Legal Studies Program, Faculty of Law, Jambi University
}

Received: 26 October 2020; reviewed: 13 December 2020; Accepted: 02 July 2021

\begin{abstract}
This study analyses the failure of the Perindo Party, PSI, Garuda Party, and Berkarya Party as new political parties in the 2019 election contestation in Jambi Province. This study was a qualitative descriptive study, and data were obtained through observation, interviews, and archival records. After collecting the data, the data were analyzed using interactive model analysis. This study showed that the failure of these four new political parties in Jambi Province was related to the absence of figures that were widely known to the public. The characteristics of local politics, which were affected by emotional and primordial ties, made political parties adopt the technocrat aristocratic pattern to maintain their existence in the political arena in Jambi Province. The success of political parties in Jambi Province was closely related to public voting behaviour that was influenced by figures with technocrat backgrounds in large parties. The existence of old parties proved it because they had famous figures from former officials or state apparatus and public officials' families such as Hasan Basri Agus (Golkar) and Nurdin Hamzah family (PAN).
\end{abstract}

Keywords: Figure ID; Voting Behavior; Technocratic Nobility; New Party

How to Cite: Muhammad, H.A., \& Nopyandri, (2021). The Failure of New Political Parties and ID Figures Nobility of Technocrats in Analysis of Voting Behavior in Jambi. JPPUMA: Jurnal Ilmu Pemerintahan dan Sosial Politik UMA (Journal of Governance and Political Social UMA), 9 (2): 117-128

\begin{tabular}{lr}
\hline${ }^{*}$ Corresponding author: & ISSN 2549-1660 (Print) \\
E-mail: Hattaabdimuhammad @gmail.com & ISSN 2550-1305 (Online)
\end{tabular}




\section{INTRODUCTION}

Studies on the failure of political parties in general election contestation are often analyzed with an institutionalism approach (Katz \& Mair, 1995). The institutionalism approach is used to compare the institutionalization of political parties in developed countries with developing countries. Based on this perspective, the failure of political parties in election contestation was shown by several indicators where political parties were not wellinstitutionalized and did not have a solid foundation and legitimacy continuously adjusted by party political actors (Mainwaring \& Scully 1995). Furthermore, if these indicators are expanded, the survival of political parties, in general, can be influenced by the level of institutionalization, election volatility, and ideological choices (Mainwaring \& Torcal, 2004).

The collapse of Suharto's New Order authoritarianism became the initial phase of institutional reform in political institutions in Indonesia, including those related to the party system. In the political field, one of the visible processes is the introduction of direct general elections and providing access to public participation (Choi, 2007a). To respond to it, the community then competed to establish various political parties. Since the direct general election was held in 2004 until the last election in 2019, the growth of political parties in Indonesia has increased significantly.

It is recorded that since the legislative general election began in 2004, the total number of political parties participating in the electoral contest has generated a number with various names with different backgrounds. In detail, the 2004 election was attended by 24 political parties participating in the election; The 2009 general election saw an increase in the number of political parties participating in the general election to 38 parties at the national level and six local parties in Aceh; In 2014 passed 12 political parties participating in the polls at the national level and three local parties in Aceh, and in 2019 gave 16 political parties participating in the elections at the national level and four local parties in Aceh. (Efriza, 2019).

This study discusses the failure of new political parties in the 2019 legislative general election contestation at the local political level with a different approach, namely examining the breakdown of voting behaviour. This study revealed that identifying figures with technocratic aristocratic backgrounds could influence voting behaviour, which political scientists have never used to explain electoral characteristics in local political contestations in Indonesia (Liddle \& Mujani, 2007; Mujani, Liddle, \& Ambardi, 2012).

Voting behaviour in politics is considered political processes or activities carried out by individuals or groups required by the state to carry out their rights and obligations in political behaviour activities, namely participating in the ongoing election process (Flanagan, 2010). The conceptual explanation of voting behaviour focuses on the decision to choose or not, to whom the choice is addressed and how to choose (Diwakar, 2010). To be specific, choosing has the meaning of a decision choice. Consequently, the essence of the study of voting behaviour is to position "the motivations which determine vote choice" (Evan, 2004). Voting behaviour does not merely represent individual actions,

Hence, culturally, choosing the community will play an essential role in explaining the relationship between one's behaviour as part of the community and the political conditions in the area. The community environment will determine a significant influence in shaping a person's behaviour. Due to the building construction of the fundamental behaviour of the individual, it is still concerned with the distribution of profit and loss in the form of a material basis that will impact himself and his environment (Halim, 2017).

Studies related to voting behaviour are often viewed from socio-religious, sociocultural to socio-economic variables as a unit of analysis (Gaffar, 1992; King, \& Dwight 2001; Ananta, Arifin, \& Surayadinata, 2004). In the perspective of post-reform local politics, the study of the voting behaviour of urban communities gives a tendency towards social exchanges that are beneficial to individuals in making political decisions (Halim, 2017). However, the direction of the study of voting behaviour is still primarily based on the family patronage approach where they have a network down to the base so that they can 
monopolize the electoral vote bassist, influence public support and change the sociocultural community (Sutisna, 2017 \& Purwaningsih, 2015). In the areas with the traditional solid character, one's voting behaviour is based on a communal spirit by maintaining relationships and respect for relatives and neighbours in their environment so that they are easy to exploit in power contests (Sobari, 2016).

The focus of this research is the 2019 Jambi Province legislative election. The failure of a new political party in the general election contestation, namely Persatuan Indonesia Party (Perindo); Solidaritas Indonesia Party (PSI); Garuda Party; and Berkarya Party, can illustrate that the orientation of voters towards electoral contestation is influenced by the members' loyalty to local figures who have a technocratic nobility background where the network has long been built towards major political parties.

Elections with an open proportional system implemented in Indonesia provide an opportunity for political parties to maximize their ability to perform well in election contestations and maintain people's political preferences. Based on several election results in Jambi Province since the reform, the winning political parties tend to change; only in 2014 and 2019, the PDI-Perjuangan Party manage to reach the top position. Most of the old political parties in the Islamic block and the nationalist (secular) alliance showed the distribution of votes, which did not significantly shift.

New political party votes showed low numbers. Berkarya Party was an exception because it could pass its representatives to fill seats in the legislature. Meanwhile, 3 (three) other new political parties failed in the power contest.

Based on the typology scheme of political parties Larry Diamond and Richard Gunter (2001), the tendency of political parties in Indonesia to fall into the electoral category or parties that aim to win public office through elections. This category is further divided into three subtypes: "catch-all, which seeks to gain voters' votes through the appeal of broad and diverse issues and the image of the candidate; programmatic, which aims to capture voices by conveying programmatic and ideological requests; personalistic, which took the voter's votes by highlighting the personal charisma of the party leader, emphasizing the benefits that will confer on his support group and activation of clientelistic links. In this paradigm, political parties in Jambi Province display both catch-all and personalistic characters based on the graph above.

Based on the description above, most of the writings above are very limited in examining the failure of new political parties with an approach to voting behaviour based on the perspective of technocrat nobility. This paper is intended to explore the extent to which character figures from the standpoint of technocrat nobility influence one's political choices. This theme is essential because no one has studied it earlier. Furthermore, due to the perspective of local politics, the tendency of regions to have different characters, metamorphoses sharply but in the principles of liberal democracy, instead of helping the growth of Indonesia's democratization, voting behaviour based on technocratic nobility has the potential to support the cultural-political climate by strengthening the figure-ID and ignore the identity of the political party (Party - ID).

\section{RESEARCH METHOD}

This paper selected new political parties in Jambi Province that took part in the 2019 legislative general election, namely the Persatuan Indonesia Party (Perindo), Solidaritas Indonesia Party (PSI), Garuda Party, and Berkarya Party, as objects of study because there were exciting phenomena. After the 2019 legislative general election was held in Jambi Province, only Berkarya Party was able to pass 1 (one) representative into the Jambi Provincial parliament, 3 (three) other new political parties failed.

To understand the power contestation in the area, this descriptive qualitative research relied on a combination of secondary information from various sources and primary data from observations, in-depth interviews with informants from different circles; both party politicians, local political observers, traditional leaders, community leaders, and the community themselves to understand the character of the Jambi people's voting behaviour deeply. Information gathering used a semi-structured open questionnaire in a small number of cases to reveal facts about 
existing social phenomena (Joubish, Khurram, Ahmed, Fatima, \& Haider, 2011).

Determination of informants was based on an understanding of the required data taken from various levels of the political infrastructure layer (District/City, District and Village), multiple groups and stakeholders at the community level. The various levels were only taken by a few representatives who were considered to have the ability to provide objective information. This method was deemed appropriate because it was able to answer the phenomenon of the failure of new political parties in the 2019 election power contestation in a regional perspective, namely in Jambi Province.

Used Various primary and secondary data to understand the phenomena that occur. Data analysis was carried out using interactive model analysis, where at the initial stage, a systematic coding process was carried out to find concepts, categories and prove initial hypotheses (Miles, Huberman, \& Saldana, 2014). Then an analysis was carried out comparing previous research findings to show novelty or confirm existing theories. In addition, confirmation of the validity of the data was carried out repeatedly through a careful search of information.

The discussion starts from the description of the distribution of the population's ethnicity in Jambi Province, which is then linked to the local political dynamics of Jambi Province in the reform era. This section is essential to guide further the failure of new political parties in the contestation of regional power. When viewed from the perspective of voting behaviour, this practice is a contrast because it will study the tendency with the standpoint of institutionalism. Meanwhile, there is not much available field data regarding the relationship between the failure of political parties and voting behaviour in the contestation of power in the regions.

\section{RESULTS AND DISCUSSION}

\section{Three Voter Approaches in Making Political Decisions}

Theoretically, voting behaviour is a study in an established political science approach (Sobari, 2019). Three strategies that explain motivation in encouraging voters to make political decisions in power contests that have been the basis for reading voting behaviour, namely The Columbia Study, The Michigan Model and Rational Choice (Bartels, 2012; Roth, 2008; Campbell, Converse, 2003; Miller, \& Stokes, 1960). The three main theories are often known as sociological choice (social structure theory), psychological selection (party identification / Party - ID), and rational choice approach (sensible choice theory).

The sociological approach model emphasized the primary factors driving a person's political participation and choice through equality or emotional closeness based on social identity. Reflected sociological values based on attitudes, values, beliefs which include gender, age, ethnicity or area of residence (geopolitics), religion and level of piety, as well as the social class as measured by place in urban or rural areas, educational factors, income and type of work (Mujani, Liddle \& Ambardi, 2019). Several experts then emphasized the focus of the study of the sociological approach, primarily based on religion, ethnicity, and social class, all of them are the driving force of the majority (Samadhi, \& Warouw, 2009; Aspinall, \& Mietzner, 2010; Hadiz, 2010; Winters, 2011).

The assumption is that the background of a specific individual would be influenced by the control and pressure of the existing social circle to determine the voter's decision in the contestation of power. Sociological models could provide excellent explanations for the constant voting behaviour of specific individuals. It was due to the structural framework of each individual, which only changed slowly. However, the sociological model could not explain the causes of the shift in individual political choices because the primary basis of analysis of this model was the social conditions that make the individual the centre of investigation (Roth, 2008).

The second approach explained that partisan behaviour towards certain political parties is the basis for the psychological closeness between parties and voters. This approach from the University of Michigan tends to be relatively new in Indonesia (Mujani, Liddle \& Ambardi, 2019). The focus of the psychological process explained that group membership and family influence could shape political party identification behaviour. Party identification can directly influence one's 
political choices. Furthermore, other patterns of party identification behaviour formed the "intermediate behavior" before making political choices. These intermediate behaviours were attitudes towards policies, political themes raised in campaigns, group benefits, and attitudes to candidates. This focus can encourage a person's confident choices (Sobari, 2019).

In summary, voter identification with a particular political party that displayed party identity, issue orientation and perspective towards candidates, and support for individual leaders were the most critical partisan choiceforming factors. The identity of a political party was considered as a concrete identification in the person's view. Closely, someone sought to feel emotionally involved with a political party. Thus, this identification is interpreted as party ID (Dalton, 2002).

The third approach, a person's choosing behaviour, was based on a rational choice model or a rational choice approach. The sensible choice approach placed an individual as an actor who calculates their personal or individual actions (Downs, 1957; Olson, 1965; Riker and Ordeshook, 1968). The rational approach perspective underscores that every effort must benefit the individual himself, not any group of which the individual is a member (Mujani, Liddle \& Ambardi, 2019).

This approach was a critique of the two previous approaches, namely the sociological and psychological approaches. In this profitand-loss perspective, someone placed economic theory as a significant consideration (Mujani, Liddle \& Ambardi, 2012; Bartels, 2012). The premise raised that if the assumption of rational choice was able to explain the market mechanism, it should also explain the nature of politics. The operation of this model was based on all decisions that have been made by voters that were rational, that is, guided by self-interest and implemented by the principle of maximizing benefits. However, something that needs to be understood is that the election mechanism is part of choosing public officials to produce things owned by the public. Therefore one's contribution to the election did not provide personal incentives. Political choices with a rational approach were always oriented to the results achieved by certain parties or candidates in elections (Roth, 2008).
The three models of voting behaviour approach above did not have to contradict each other. In the social structure of society, the three models could be selected by individuals in the process of power contestation because all background factors can have a significant effect. Therefore, how much was the dominant factor and could explain a person's political choice better would have the possibility to be applied.

\section{Ethnic Distribution and Social Culture of Jambi Province}

Geographically, Jambi Province is located in the Central part of Sumatra Island, with $53,435.92 \mathrm{~km} 2$ consisting of $48,989.98 \mathrm{~km} 2$ of land and $4,445.94 \mathrm{~km} 2$ of land the sea with a coastline of 223,025 km. The largest land area in Jambi Province is in Merangin Regency, with an area of $7,508 \mathrm{~km} 2$ or $15.31 \%$ of the total area of Jambi Province, followed by Tebo Regency and Sarolangun Regency with an area of 6,205 km2 and 5,948 km2, respectively. Based on BPS data (2019), the population of Jambi Province was 3,570,272 people, and the average density level was 71.18 people/km2, with the highest average density in Jambi City at 2,911.47 people/ $\mathrm{km} 2$ and the lowest in Kabupaten Jambi. Tanjung Jabung Timur was 40.11 people/km2.

Socially, the structure of society in Jambi Province is similar to what also appears in Indonesia, as stated by Nasikun (2004: 34), which is characterized by two unique characteristics horizontally and vertically. Horizontally, the structure of Indonesian society is characterized by the fact that there are social units based on differences in ethnicity, religion, customs, and regional differences. Meanwhile, vertically, the structure of Indonesian society is marked by sharp differences between the upper and lower layers. Jambi Province also shows its status as a plural region like Indonesia, as described above. In general, the demographic composition of Jambi Province can be divided into two major groups, namely: indigenous peoples and migrants (Indigenous Institutions of Jambi Province, 2003, pp. 30-31). Indigenous people have lived in this area for a long time since their ancestors until now. Those included in this category were Weddoid in the form of the Anak Dalam Tribe (Kubu Tribe) and the Malays consisting of Proto 
Malays (Bajau Tribe, Kerinci Tribe, and Batin Tribe) and Dentro Melayu (Movement Tribe, Penghulu Tribe and Jambi Malay Tribe).

Meanwhile, the immigrant population were people who come to the Jambi area, both from Indonesia and abroad, grouped into Indonesians and Foreigners. Indonesian people consisted of Bugis, Javanese, Banjarese, Batak, Palembang, Sundanese, and others, while foreigners were Indians, Arabs, Chinese, Dutch, etc. Indigenous people have lived in this area for a long time since their ancestors until now. Those included in this category were Weddoid in the form of the Anak Dalam Tribe (Kubu Tribe) and the Malays consisting of Proto Malays (Bajau Tribe, Kerinci Tribe, and Batin Tribe) and Dentro Melayu (Movement Tribe, Penghulu Tribe and Jambi Malay Tribe). Meanwhile, the immigrant population was people who come to the Jambi area, both from Indonesia and abroad, grouped into Indonesians and Foreigners. Indonesian people consist of Bugis, Javanese, Banjarese, Batak, Palembang, Sundanese, and others, while foreigners are Indians, Arabs, Chinese, Dutch, etc.

The social structure of the Jambi Province community based on ethnicity consists of Malay, Javanese, Sundanese, Palembang, Batak, Minang, Bugis, Banjarese, Arabic, Indian and Chinese (Lindayanty, 2013: 209). Ethnic Malay was the most dominant social group in the community structure because it is a native of Jambi Province in general (Jambi Province Customary Institution, 2003, pp. 30-31). Other ethnic groups (Sundanese, Batak, Palembang, Minang, Banjarese, Bugis, Chinese) were immigrants whose existence was more due to economic factors, even historically it has been going on for a long time since the ancient kingdom. These various ethnicities came to this area, especially Jambi City, because of its existence which has long been known as the centre of government, especially since the establishment of Jambi Malay Sultanate and trade for being an export port of various natural resources. This unique position has made Jambi City run into a very significant development compared to other regions in Jambi Province. Various public facilities and employment opportunities were available and more complete in Jambi City. In addition to economic factors, the presence of ethnic immigrants in Jambi City was also related to political factors, such as Java which was closely related to Jambi's relations in the past with the Singosari Kingdom in the Pamalayu Expedition (Halim \& Pahrudin HM, 2020, p. 228), while connected to religion, there were ethnic Arabs in the context of spreading Islam and India to spread Hinduism in the kingdoms that have ruled in Jambi City in the past.

In terms of religion, the social structure of the Jambi Province community consisted of various religions, namely Islam, Christianity, Catholicism, Hinduism, Buddhism and Confucianism, although Muslims were the majority. Based on BPS data (2019), the social structure of the Jambi Province community from an economic perspective was generally divided into three major sectors, namely agriculture (47.35\%), trade $(15.43 \%)$ and services (12.15\%). The farmer/fisherman group was almost entirely a profession occupied by ethnic Malays; the merchant group was mainly ethnic Chinese, Minang, Bugis, Batak, and Sundanese. In contrast, the service/employee group was filled primarily by ethnic Malays, Javanese, and Palembang (BPS, 2019).

As part of the composition of the largest population in Jambi Province, the Malays had a high spirit of togetherness and mutual assistance (Ministry of Education and Culture of the Republic of Indonesia, 1986). If any of them needed help, the others would immediately assist. The Malays were also familiar with the system of social stratification. The high and low status of a person was highly dependent on his rank, education and wealth. In a Malay community, if someone has more position, education, and wealth than others, he will have a high social status.

The life of Jambi community from a socio-cultural perspective was Adat Bersendikan Syara', Syara' Bersendikan Kitabullah (Ministry of Education and Culture, 1986). Jambi Regional Community was a heterogeneous society, it can be seen in the values contained in the traditional advice; dimano tembilang tercacak disitu tanaman tumbuh, dimano bumi dipijak, disitu langit dijunjung, dimano larasnya dicencang, disitu airnya diminum, tidak membawa cupak dengan gantang (means wherever you live, you have 
to be able to adapt with the environment). Structurally, the former Jambi region was divided into: Daerah Bangsa Nan Dua Belas; Daerah Nan Berbatin; Luak Nan Berpenghulu denganjenjang-jenjang nan berajo, rantau nan berjenang, loak berpenghulu, kampung nan betuo, rumah nan bertengganai. In everyday life, Jambi people were famous for their mutual cooperation and openness, which was known as berat samo dipikul, ringan samo dijinjing. In general, when deciding on a collaborative work, it is discussed; bulat aek dek pembuluh bulat kato dimufakat.

\section{Local Dominant Man, Nobility of Technocrats and New Political Parties in Jambi}

It is well known that the 1998 reforms brought down the power of the New Order and created a new political system in the form of regional autonomy or decentralization. In addition to the positive side that made the public participate widely in various fields, decentralization also left negative aspects. The era of decentralization gave rise to the phenomenon of ' local dominant men' who have based in the regions. Money politics and violence were increasingly colouring local political battles. "Local dominant men" relied on culturally pre-existing agents of violence such as the champions in Banten or by forming new militias. In addition to using political parties, "local dominant men" in some areas also mobilized by exploiting ethnic and religious politics. Ethnic political power was much more relevant at the local level than at the national level. In the decentralized era, local politics in Indonesia became an arena for local elites to take advantage of electoral democracy to secure local level executive and legislative positions to their families, cronies, and loyalists (Aspinall \& Mietzner, 2010 pp. 715). Several "political clans" have succeeded in making Provinces or Regencies/Cities their jurisdictions and keeping decentralization away from the "grassroots" of democracy. The local elite's ability was supported by its wealth and political power to buy votes or manipulate the religious and ethnic loyalties of the local community. In the decentralized era, local politics in Indonesia became an arena for local elites to take advantage of electoral democracy to secure local level executive and legislative positions to their families, cronies, and loyalists (Aspinall \& Mietzner, 2010 pp. 7-15). Several "political clans" had succeeded in making Provinces or Regencies/Cities their jurisdictions and keeping decentralization away from "grassroots" democracy. The local elite's ability was supported by its wealth and political power to buy votes or manipulate the religious and ethnic loyalties of the local community. In the decentralized era, local politics in Indonesia became an arena for local elites to take advantage of electoral democracy to secure local level executive and legislative positions to their families, cronies, and loyalists (Aspinall \& Mietzner, 2010 pp. 7-15). Several "political clans" had succeeded in making Provinces or Regencies/Cities their jurisdictions and keeping decentralization away from "grassroots" democracy. The local elite's ability was supported by its wealth and political power to buy votes or manipulate the religious and ethnic loyalties of the local community. Several "political clans" had succeeded in making Provinces or Regencies/Cities their jurisdictions and keeping decentralization away from "grassroots" democracy. The local elite's ability is supported by its wealth and political power to buy votes or manipulate the religious and ethnic loyalties of the local community.

In the reform era, one of the factors to change the New Order's centralized order and support the realization of a rational, responsible and responsive bureaucratic structure was decentralization. However, in reality, the decentralization process in Indonesia was considered not to be correlated with strengthening political democracy. The shifts in power that occurred after the New Order only occurred in context and did not change the material basis. The process of domination of the new order elite in the political and economic fields was still ongoing. It was proved by the parties who obtained benefits from the decentralized system, including individuals and groups who previously acted as state operators and local officials of the new order, small/medium entrepreneurs with big ambitions who have political connections and a group of former accomplices of the new order regime ( Hadiz, 2011).

The reforms in Indonesia were also taking place in Jambi. The reforms made all political figures in Jambi, both young and old, 
feel they had the same opportunity to gain political power in the legislative and executive branches. Previously, upheld the principle of seniority in the recruitment of leaders both in the legislature and the executive. The reforms seem to promise an elite circulation in Jambi Province. The first battle began with the struggle of the parties in the 1999 election. In the first multi-party election after the New Order, Golkar Party still became the first winner in the 1999 election. However, there was a significant decrease in votes compared to the previous election. PDI-P Party got a substantial increase in polls from the last election by becoming the second winner. It was followed by Persatuan Pembangunan Party and two new reformed parties, namely Amanat Nasional Party and Kebangkitan Bangsa Party. The 1999 elections in Jambi provided an opportunity for new political actors resulting from reforms and old political actors who could survive to compete for political positions such as Governor, Chair of the Regional People's Representative Assembly or Members of Indonesian House of Representatives. The 1999 election seemed to be a sign of a shift in political power in Jambi. The gate that opened in the first post-reform election continued with subsequent democratic parties. As a result, three prominent figures in local politics in Jambi emerged from a series of post-reform elections. The early two were 'old players' whose existence became increasingly significant after the 1999 election through the success of Golkar Party and PAN, which played a role as Dominant local men (Hutabarat, 2012), while the last one was 'new players' innovating using bureaucratic channels to gain an important position in Jambi politics.

First, the wealthiest indigenous businessman who served as Chairman of the DPW PAN Jambi Province, Zulkifli Nurdin, was elected as a Member of the Indonesian Parliament. Before the reform, Zulkifli Nurdin was active in Golkar Party and has been the Treasurer of the Golkar Party since 1996. Second, a local government contractor who became the Chairman of Jambi Provincial Golkar Party Regional Representative Council, Zoerman Manap, was elected Deputy Chairman of the Jambi Provincial Regional People's Representative Assembly for the 1999-2004 period. Zorman Manap is the first child of the second Governor of Jambi, Haji Abdul Manap. These figures are also active in the Indonesian National Construction Executor Association (Gapensi), the Chamber of Commerce and Industry (Kadin), and various associations of entrepreneurs or contractors in Jambi. Zulkifli Nurdin was the Chairman of Gapensi and Kadin in Jambi, while Zoerman Manap was the Chairman of Gapensi in Jambi. Third, Hasan Basri Agus (HBA), a bureaucrat who built his political career through the bureaucracy. Unlike the two Dominant local men above, Hasan Basri Agus (HBA), born on August 30, 1953, built his political network through his fantastic bureaucratic career. In 1988-1990 he was successively the sub-district head of Maro Sebo, Mersam and Muara Tempest. In 19941997 he served as the Head of the Civil Registry Agency for Bungu Tebo Regency, the Regional Secretary for Batanghari and the Jambi Province Personnel Bureau. The peak of his bureaucratic career was achieved in 19992006 as Regional Secretary of Jambi Province. His political career began in 2006-2011 as Regent of Sarolangun and Governor of Jambi (2010-2015). He has been Chairman of the Demokrat Party in the Regional Representative Council of Jambi Province (2010-2015). He then joined Golkar Party in 2017 and was elected as a member of the 2019-2024 House of Representatives Jambi Electoral District by winning the most votes.

local politics in Jambi was still influenced by emotional ties and regional primordialism (Hutabarat, 2012, p. 48). The influence of dynamic and primordial relations such as family origin and background was a determining factor. These local political characteristics in Jambi were put to good use by these 'Dominant local men' by building a comprehensive and robust network. This shift in Jambi's political power showed that the reforms in Jambi had been successfully hijacked by forces who have succeeded in taking advantage of democratization on behalf of the people so that they occupied important government positions in the regions.

Zulkifli Nurdin, Zoerman Manap and Hasan Basri Agus placed their families and cronies into the government and political parties. The interaction of the three influenced Jambi's politics in the future. Sometimes they 
conflicted, and sometimes they formed a coalition. Zorman Manap as the eldest son of the late Abdul Manap, the founding figure of Jambi province and the second Governor of Jambi, succeeded in building a more robust political family in Jambi. Zorman Manap was elected as deputy chairman of Jambi Provincial Regional People's Representative Assembly (1999-2004), Chairman Of Jambi Provincial Regional People's Representative Assembly (2004-2009) and Deputy Chairman of Jambi Provincial Regional People's Representative Assembly (2009-2014). His younger brother, Arifien Manap, was elected Mayor of Jambi for two terms (1998-2003 and 2003-2008). His son, Nuzul Prakasa Zoerman, was elected to the Jambi City Regional People's Representative Assembly (2004-2009 and 2009-2015). His nephew, Arif Munandar, was selected as Regional Secretary of West Tanjung Jabung Regency. Her sister-in-law, Maesita Arifin, was elected as Deputy Chairperson of the Jambi City Regional People's Representative Assembly (2009-2015). Zoerman Manap and his family also controlled Golkar Party. Zoerman served as Chairman of the Regional Representative Council of the Golkar Party of Jambi Province for three terms. Arifien Manap became Chairman of the Regional Representative Council Golkar Party Jambi City. Nuzul Prakasa Zoerman became Deputy Chairperson of Jambi City Golkar Party Regional Representative Council. Mesita Arifien became Deputy Chairperson of the Jambi City Golkar Party Regional Representative Council.

It was not only families who got 'benefit' from the presence of this Dominant local man in the local political arena in Jambi. The party where the figure belongs also gained positive benefits through the flow of votes in the elections held. The Regional Representative Council of Jambi Province Golkar Party, led by Zoerman Manap and continued by his close people, obtained significant results in several elections. In the 2014 election, the Golkar Party was ranked first in the number of votes with 288,724 votes (17.06 per cent), while in the 2019 election, the party inherited from the New Order won 360,297 votes Jambi Province.

Zulkifli Nurdin, the eldest son of the late Nurdin Hamzah, the most prosperous indigenous businessman in Jambi, also succeeded in building a more robust and more influential political family in Jambi. Zulkifli Nurdin was elected as Governor of Jambi for two terms (1999-2004 and 2005-2010). His wife, Ratu Munawaroh Zulkifli, was elected as a Member of the Indonesian Parliament (20092014). His son, Zumi Zola Zulkifli, was elected Regent of Tanjung Jabung Timur (2011-2016) and became Jambi (2015-2018). His nephew, Sum Indra, was selected as Deputy Mayor of Jambi (2008-2013) and since 2019 has been elected to Indonesia Regional Representative Council - Representative of Jambi Province. Zulkifli Nurdin and his family also controlled the National Mandate Party. Zulkifli Nurdin served as Chairman of the Regional Representative Council of PAN Party Jambi Province for two terms and finally became the Chairperson of the MPP DPW PAN Jambi Province.

Such Golkar Party, Amanat Nasional Party led by the family of Nurdin Hamzah and followed by his colleagues also gained significant votes in the elections held in Jambi Province. For example, in the 2009 elections, the party born after this reformation won eight seats in the Jambi Provincial Regional People's Representative Assembly. However, it decreased to five seats in 2014 and increased again in 2019 with seven seats.

Meanwhile, Hasan Basri Agus, as one of the central figures in Jambi's local politics, started his career in the bureaucratic circle. As the sub-district head, the head of the service, and the regional secretary of Jambi Province, Hasan Basri Agus has passed. Hasan Basri Agus' political career began as Regent of Sarolangun 2006-2011 and Governor of Jambi (2010-2015). Such the two previous Jambi local political figures, Hasan Basri Agus, also led a political party by becoming the Chairman of Jambi Provincial Democratic Party Regional Representative Council (2010-2015), and later joined the Golkar Party in 2017 and was elected as a member of the 2019-2024 Jambi Regional House of Representatives election by winning the most votes. Unlike the two figures above, Hasan Basri Agus did not place his family in the leadership ranks of the political parties he leads.

Such Golkar Party and PAN Party, the Demokrat Party, which Hasan Basri Agus previously led, also gained a significant electoral advantage with the presence of this figure. Based on the results of the 2014 
election, the Democrat Party won nine seats in the Jambi Provincial Regional People's Representative Assembly, an increase of one heart compared to the 2009 election. Meanwhile, in the 2019 election, when Hasan Basri Agus was no longer in SBY's party, the Democrat Party again decreased to seven seats in the Jambi Provincial Regional People's Representative Assembly. Meanwhile, the Golkar Party, where Hasan Basri Agus worked after moving from the Demokrat Party, in the 2019 Election won 360,297 votes in Jambi Province or ranked third with only 0.3 per cent adrift of Gerindra in the second position.

Table 1

Dynamics of Political Parties Vote Gain in Jambi Province

\begin{tabular}{lllll}
\hline $\begin{array}{l}\text { Political } \\
\text { party }\end{array}$ & $\mathbf{2 0 0 4}$ & $\mathbf{2 0 0 9}$ & $\mathbf{2 0 1 4}$ & $\mathbf{2 0 1 9}$ \\
\hline Democrat & 5.18 & 14.46 & 16.46 & 10.4 \\
\hline Gerindra & - & 4.34 & 11.42 & 11.7 \\
\hline PDI-P & 11.02 & 9.65 & 14.06 & 14.5 \\
\hline Golkar & 24.97 & 12.24 & 13 & 11.2 \\
\hline NasDem & - & - & 5.75 & 5.8 \\
\hline Hanura & - & 6.19 & 7.01 & 3.0 \\
\hline PKB & 6.1 & 3.95 & 7.2 & 9.9 \\
\hline PAN & 16.14 & 13.72 & 9.75 & 10.4 \\
\hline PPP & 5.82 & 4.2 & 5.27 & 5.7 \\
\hline UN & 3.74 & 3.19 & 3.46 & 2.2 \\
\hline VFD & 4.88 & 5.11 & 4.72 & 7.4 \\
\hline Perindo & - & - & - & 1.6 \\
\hline work & - & - & - & 1.81 \\
\hline PSI & - & - & - & 0.8 \\
\hline Garuda & - & - & - & 0.4 \\
\hline PKPI & - & - & - & 0.3 \\
\hline source: Jambi Provincial KPU, 2019. &
\end{tabular}

As previously mentioned regarding the political characteristics in Jambi, the old parties had central figures who were able to gain popular votes in a series of post-reform elections held. Apart from being well-known figures for their wealth and social structure, these prominent figures were also people who in the past were public officials. This series of privileges allowed the old parties to gain significant votes in elections and led their representatives to occupy various public positions, both in the executive and legislative realms. On the other hand, as shown in Table 1 above, the new parties in the 2019 election contestation, such as Perindo and the Indonesian Solidarity Party (PSI), only rely on new figures that did not have a socio-political background that can hypnotize the public. Only Berkarya Party as a new contestant in the 2019 Election, was able to speak a lot by placing one representative in the Jambi Provincial Regional People's Representative Assembly. The party, created by Suharto's youngest son, was also filled with people who, in the past, were public officials who held various strategic positions in provinces and districts/cities.

This is a local political phenomenon in Jambi that greatly influenced the existence of political parties in the heart of Sumatra Island. In Jambi society, the orientation of voters towards electoral contestation was influenced by partisan loyalty to local figures who had a technocratic nobility background where the network between them has long been built against major political parties. The nobility of the technocrats, on the one hand, was individual who was previously state operators and local officials of the new order in Jambi Province which in the reform era later morphed into local politicians who controlled various political parties. The working mechanism was carried out using these politicians controlling the bureaucratic structure and social security network distributed to local communities. As a result, local people realized that their relationship was solid and could be used at any moment of the ongoing election.

On the other hand, these 'local Dominantmen' are individuals who incidentally are bureaucrats, taking advantage of their status as bureaucrats to engage in practical politics. After retiring and those who were still active but decided to end their career as bureaucrats, they moved to become local politicians by joining political parties. As a result, in every election held in Jambi Province, the old parties were able to gain significant public votes to secure their political positions.

\section{CONCLUSION}

The existence of local Dominantmen and bureaucratic aristocrats greatly affected one's political choices. It can occur in areas with regional political characteristics influenced by emotional and primordial ties, such as Jambi 
Province. Therefore, political parties applied the pattern of technocrat nobility to maintain their existence in the political arena in Jambi Province. The old parties that owned former public officials with emotional ties succeeded in attracting electoral support from the community in a series of elections. In contrast, the new parties failed to compete for political positions at every level in Jambi Province.

\section{BIBLIOGRAPHY}

Ananta, A., Arifin, E. N., \& Suryadinata, L. (2004). Indonesian electoral behaviour: a statistical perspective. Singapore: ISEAS.

Aspinall, E., \& Mietzner., M. (2010). Problems of democratization in Indonesia: elections, institutions and society. Singapore: Institute of Southeast Asian Studies Press.

Badan Pusat Statistik (2019). Provinsi Jambi dalam angka 2019. Kota Jambi: BPS Provinsi Jambi.

Bartels, L., M. (2012). The study of electoral behaviour: the oxford handbook of American elections and political behaviour. Oxford: Oxford University Press.

Campbell, A. P. E., Converse., W., Miller, E., \& Stokes, D., E. (1960). The American voter. New York: Wiley.

Choi, N. (2007). 'Elections, parties and elites in Indonesia's local politics. South-East Asia Research, 15(3), 325-354. https://doi.org/10.5367/000000007 782717731

Dalton, R. J. (2002). Citizen politics: public opinion and political parties in advanced industrial democracies. New York: Chatham House Publishers.

Departemen Pendidikan dan Kebudayaan RI (1986). Upacara Tradisional dalam Kaitannya dengan Peristiwa Alam dan Kepercayaan Daerah Jambi. Jakarta: Author.

Diwakar, R. (2010). Voting behaviour. The Encyclopedia of Political Science, 1 - 6.

Diamond, L., \& Gunther, R. (2001). Political parties and democracy. Baltimore, MD: John Hopkins University Press.

Downs, A. (1957). An economic theory of democracy. New York, NY: Harper \& Row.

Evans, J. A. (2004). Voters and voting: an introduction. London: Sage Publications.

Efriza. (2019). 'Eksistensi partai politik dalam persepsi publik'. Jurnal Politica : Dinamika Masalah Politik Dalam Negeri \& Hubungan Internasional, 10 (1), pp. 17-38.

Flanagan, W. G. (2010). Urban sociology: images and structure. London: Rowman \& Littlefield Publishers.
Gaffar, A. (1992). Javanese voters: a case study of election under a hegemonic party system. Yogyakarta: Gadjah Mada University Press.

Halim, W. (2017). 'Perspektif pertukaran sosial dalam perilaku politik masyarakat pada pilkada Kota Malang 2013'. Politik Indonesia: Indonesian Political Science Review, 2 (2), pp. 201-226.

Halim, A \& Pahrudin HM (2020). 'The study of Seloko Adat as savety-valve to prevent religious conflict in Jambi City, Indonesia'. JSP: Jurnal Ilmu Sosial dan Ilmu Politik, Vol. 23, Issue 3, March 2020, pp. 223-236. DOI: 10.22146/jsp.50532.

Halim, A \& Pahrudin HM (2019). 'The role of local wisdom as religious conflict resolution in Jambi Indonesia'. Walisongo: Jurnal Penelitian Sosial Keagamaan. Vol. 27 No. 2 (2019) pp. 353-374. DOI: http://dx.doi.org/10.21580/ws.27.2.4358.

Hadiz, V. R. (2010). Localizing power in postauthoritarian Indonesia: a Southeast Asian perspective. Stanford, CA: Stanford University Press.

Hutabarat, Melvin Perjuangan (2012). 'Fenomena orang kuat lokal di Indonesia di era desentralisasi, studi kasus tentang dinamika kekuasaan Zulkifli Nurdin di Jambi'. Thesis. Program Pascasarjana Ilmu Politik Universitas Indonesia.

Joubish, M. Farooq, Khurram, M. A., Ahmed, A., Fatima, S. T., \& Haider, K. (2011). 'Paradigms and characters of good qualitative research. Worl Applied Sciences Journal, 12 (11), pp. 2082-2087. Retrieved from http://www.idosi.org/wasj/wasj12(11)/23. pdf

King., \& Dwight, Y. (2001). Half haltered reform: electoral institution and the struggle for democracy in Indonesia. Westport, Connecticut, Praeger.

Katz, R. S., \& Mair, P. (1995). 'Changing models of party organization and party democracy: the emergence of the cartel party. SAGE Social Science Collections: Party Politics, 1(1), pp. 528.

https://doi.org/10.1177/135406889 5001001001

Lembaga Adat Provinsi Jambi (2003). Dinamika adat Jambi dalam era global. Kota Jambi: Author.

Liddle, R.W., \& Mujani, S. (2007). 'Leadership, party, and religion: explaining voting behavior in Indonesia'. Comparative Political Studies, 40 (7), pp. 832 - 857.

Lindayanty. (2013). Jambi dalam sejarah 15001942. Kota Jambi: Dinas Kebudayaan dan Pariwisata Provinsi Jambi. 
Mainwaring, S., \& Scully, T. (1995). Building democratic institutions: party systems in Latin America. Stanford. CA: Stanford University Press.

Mainwaring, S., \& Torcal, M. (2006). Party system institutionalization and party system theory after the third wave of democratization. London: SAGE Social Science Collections.

Mujani, S., Liddle, R.W., \& Ambardi, K (2012). Kuasa rakyat. Jakarta: Mizan.

Mujani, S., Liddle, R.W., \& Ambardi, K (2019). Kaum demokrat kritis, analisis perilaku pemilih Indonesia sejak demokratisasi. Jakarta: Kepustakaan Populer Gramedia.

Nasikun (2004). Sistem sosial Indonesia. Jakarta: PT. RajaGrafindo Persada.

Olson, M. (1965). The logic of collective action: public goods and the theory of groups. Cambridge. MA: Harvard University Press.

Purwaningsih, T. (2015). Politik Kekerabatan dan Kualitas Kandidat di Sulawesi Selatan. Jurnal Politik, 1 (1), 97 - 123

Riker, W.H., \& Ordeshook. P. C. (1968). A Theory of the Calculus of Voting. American Political Science Review, 62 (2), 25-43
Roth, D. (2008). Studi pemilu empiris: sumber, teori, instrumen dan metode. Jakarta: FriderichNaumann-Stiftung fur die Freiheit.

Saldana, Miles., \& Huberman. (2014). Qualitative data analysis. USA: SAGE Publications.

Samadhi, W. P., \& Warouw, N. (2009). Building democracy on the sand: advances and setbacks in Indonesia. Yogyakarta \& Jakarta: Demos \& PCD Press.

Sutisna, A. (2017). 'Gejala proliferasi dinasti politik di Banten era kepemimpinan gubernur Ratu Atut Chosiyah'. Politik Indonesia: Indonesian Political Science Review, 2 (2), pp. 100-120.

Sobari, W. (2016). 'Anut grubyuk in the voting process: the neglected explanation of Javanese voters (preliminary findings)'. Southeast Asian Studies, 5 (2), 239-268. https://doi.org/10.20495/seas.5.2 2 $\underline{39}$

Sobari, W. (2019). 'Capacity and adequacy: explicating voting behavior in a multilevel and concurrent local election'. Journal of Political and Policy, 2 (1), pp. 1-32.

Winters, J. A. (2011). Oligarchy. Cambridge: Cambridge University Press. 